THE USE OF BODIES 

Crossing Aesthetics

Werner Hamacher

Editor 
Stanford

University

Press

Stanford

California

2016 


\section{THE USE OF BODIES}

Homo Sacer IV, 2

Giorgio Agamben

Translated by Adam Kotsko 
Stanford University Press Stanford, California

English translation (C) 2015 by the Board of Trustees of the Leland Stanford Junior University. All rights reserved.

The Use of Bodies was originally published in Italian in 2014 under the title L'uso dei corpi (C) 20I4, Neri Pozza Editore, Vicenza.

No part of this book may be reproduced or transmitted in any form or by any means, electronic or mechanical, including photocopying and recording, or in any information storage or retrieval system without the prior written permission of Stanford University Press.

Printed in the United States of America on acid-free, archival-quality paper

Library of Congress Cataloging-in-Publication Data

Agamben, Giorgio, 1942- author.

[Uso dei corpi. English]

The use of bodies : Homo sacer IV, 2 / Giorgio Agamben ; translated by Adam Kotsko.

pages $\mathrm{cm}$. - (Meridian : crossing aesthetics)

"Originally published in Italian in 20I4 under the title

L'uso dei corpi."

Includes bibliographical references. ISBN 978-0-8047-9234-9 (cloth : alk. paper)

ISBN 978-o-8047-9840-2 (pbk. : alk. paper)

ISBN 978-0-8047-986I-7 (ebook)

I. Human body (Philosophy)

2. Philosophical anthropology. I. Kotsko, Adam,

translator. II. Title. III. Series: Meridian (Stanford, Calif.)

B36II.A43U8613 2016

195 - dc23

201503289I 
A boy from Sparta stole a fox and hid it under his cloak, and because his people, in their foolishness, were more ashamed of a botched robbery than we fear punishment, he let it gnaw through his belly rather than be discovered.

-Montaigne, Essais, I, XIV

... it's the fox that boy stole

and it hid in his clothes and it ripped his thigh ...

-V. Sereni, "Appointment at an Unusual Hour"

The free use of the proper is the most difficult thing.

-F. Hölderlin 
